\title{
KLASİK DÖNEM OSMANLI HUKUKUNDA KÖLELİĞİN SONA ERME YOLU OLARAK TEDBİR*
}

\author{
Arş. Gör. Yasemin KURTOĞLU*
}

\begin{abstract}
ÖZET
Geçmişi tarihin en eski dönemlerine kadar uzanan kölelik kurumu İslam hukuku içerisinde de kendisine yer bulmuş, bu doğrultuda bir İslam devleti olan Osmanlı Devleti'nde de varlığını devam ettirmiştir. Kendisinden önceki döneme kıyasla kölelik kurumunun şartlarını önemli oranda iyileştiren İslam hukuku kurallarına Osmanlı Devleti de sadık kalmış, köleliğe geçiş ve kölelikten çıkış da İslam hukukunun öngördüğü şekilde uygulamada hayat bulmuştur.

'Klasik Dönem Osmanlı Hukuku'nda Köleliğin Sona Erme Yolu Olarak Tedbir' başlıklı bu çalışmada ilk olarak İslam hukukunda kölelik sebepleri ve köleliğin sona erme yolları hakkında genel bilgiler verildikten sonra tedbir kurumunun ele alınmasına geçilmiştir. Bu doğrultuda İslam hukukunun temel kaynaklarından yararlanılmasının yanı sıra Osmanlı Devleti özelinde ayrıntılı bir çalışma yapabilmek adına bu döneme ait fetva kitaplarından ve kadı sicillerinden geniş ölçüde yararlanılarak tedbir kurumunun niteliği, kuruluşu, çeşitleri, hüküm ve sonuçları ayrı başlıklar altında ele alınarak incelenmiştir. Yapılan incelemeler sırasında kimi yerlerde ortaya çıkan görüş farklılıklarına da yer verilmiş ve bunların bir değerlendirilmesi yapılmaya çalışılmıştır. Böylece Osmanlı hukuk sisteminde tedbir kurumuyla ilgili detaylı bir çalışma ortaya konması hedeflenmektedir.
\end{abstract}

Anahtar kelimeler: Tedbir, Kölelik, Osmanlı Devleti, İslam Hukuku, Osmanlı Hukuku.

DOI: 10.33432/ybuhukuk.882134 - Geliş Tarihi: 17.02.2021 - Kabul Tarihi: 12.07.2021.

** Bursa Uludağ Üniversitesi Hukuk Fakültesi, Hukuk Tarihi Anabilim Dalı, yasemintoros@uludag.edu.tr, ORCID: 0000-0002-9760-5326. 


\title{
TADBIR AS A WAY OF EMANCIPATION OF SLAVES IN THE CLASSICAL PERIOD OTTOMAN LAW
}

\begin{abstract}
As can be seen in all ages throughout history, slavery has also taken place in Islamic law and prolonged its existence in the Ottoman Empire as an Islamic state. Unlike its preceding, Islamic law made significant improvement on the slavery conditions which also the Ottoman Empire abided by. Becoming a slave and liberation of slaves has been practised within these laws in the whole state.

In this article titled 'Tadbir As a Way Of Emancipation Of Slaves in the Classical Period Ottoman Law', before examining the tadbir institution, firstly will be given general information about reasons of becoming a slave and methods of slave liberation. During the study, to make a detailed examination especially about the Ottoman Empire practice, fetwa books and court decisions are also referred extensively apart from the main resources of Islamic law. The institution has been studied under the topics of feature, establishment, sorts, terms and consequences. It is also tried to carry out a general assessment of the different opinions which have been faced during the study. Eventually, it is aimed to make a detailed study on tadbir in the Ottoman legal system.
\end{abstract}

Keywords: Tadbir, Slavery, Ottoman Empire, Islamic Law, Ottoman Law. 


\section{Gíriş}

Toplumsal bir gerçeklik olarak kölelik kurumuna tarihte neredeyse her toplumda rastlamak mümkündür. Sözlükte 'birinin buyruğu altında bulunan, özgür olmayan kimse’ anlamına gelen kölelik ${ }^{1}$, insanların özgürlüklerinin ellerinden alınarak başkalarının mülkiyetine tabi kılınması olarak tanımlanabilir². Diğer kişilerin mülkiyetine girmeleriyle birlikte kişilerin kendi başlarına haklara sahip olabilme ve hukuki işlemlerde bulunabilme imkanları da ellerinden alınmış olmaktadır. Bu açıdan bakıldığında köleliğin hukuken bir ehliyet arızası niteliğinde olduğu görülmektedir. Eski çağlarda köleler her türlü haktan yoksun bir şekilde efendilerinin birer eşyası olarak kabul edilmiş ve bu durum uzun yıllar boyunca esaslı bir değişikliğe uğramadan devam etmiştir.

Kölelik, İslam hukuku içerisinde de kendisini göstermiş ve bu doğrultuda bir İslam devleti olan Osmanlı Devleti de kölelik kurumuna yer veren devletlerden biri olmuştur. İslamiyet, kendisinden önceki çoğu toplumun aksine köleliğe dair köklü değişiklikler getirmiş ve kölelerin durumunun iyileştirilmesine çalışmıştır. Bu bağlamda kölelere kimi hukuki haklar tanınmış ya da efendileri tarafından kölelerine hak tanınmasını mümkün kılan düzenlemeler getirilmiştir. Böylece İslam hukukunda köleler tamamen haklardan yoksun birer birey olmaktan çıkmış ve ‘sui generis' bir ehliyete sahip hale getirilmişlerdir ${ }^{3}$. Mevcut kölelerin durumunun iyileştirilmesinin yanı sıra İslamiyet, bu kurumun yaygınlığının giderek azaltılmasını da amaçlamış ve bu doğrultuda köle olma sebeplerini azaltırken bir yandan da köleliğin sona erme yollarını arttırmıştır.

İslam hukukuna göre savaşlarda esir düşenler ya da halihazırda köle olan annelerinden doğan çocuklar köle statüsüne tabi kılınmaktadır. Köleliğin sona erdirilmesi ise İslam'ın temel kaynaklarında sıcça teşvik edilmekte ve çok çeşitli yollardan gerçekleştirilebilmektedir. Kişinin kendi kölesini tek taraflı irade beyanıyla azat edebilmesi olarak tanımlanabilecek olan gönüllü azat başta

Türkçe Sözlük (1983), Ankara, Türk Dil Kurumu Yayınları, s. 744.

Bozkurt, Gülnihal (1981) “Eski Hukuk Sistemlerinde Kölelik”, Ankara Üniversitesi Hukuk Fakültesi Dergisi, C:38, S:1, s. 65.

Aydın, M. Akif/Hamidullah Muhammed (2002) "Köle", TDV İslam Ansiklopedisi, C:26, İstanbul, s. 239. 
olmak üzere köle ile kitabet akdi yapma, kefaret olarak köle azat etme, kölenin ümmü'l veled statüsüne girmesi köleliğin sona erme yollarındandır. Sayılanlara ek olarak, kısaca efendinin ölümünün ardından kölenin özgürlüğüne kavuşması olarak tanımlanabilen 'tedbir' de bir diğer köleliğin sona erme yoludur. Tedbir, efendi tarafından tek taraflı bir hukuki işlemle kurulmakta ve bu yolla efendi, ölümünün ardından kölesinin özgürlüğe kavuşmasını garanti altına almış olmaktadır.

Tedbir, Osmanlı Devleti’nde köleliği sona erdirme yolu olarak sıkça başvurulan bir kurum olmuştur. Tedbirin uygulanmasında İslam hukukunun genel kurallarına sadık kalınmış, ortaya çıkan uyuşmazlıklar fetvalar yoluyla ya da mahkemelerde kadı önünde çözüme kavuşturulmaya çalışılmıştır.

\section{I. İSLAM HUKUKUNDA VE KLASİK DÖNEM OSMANLI HUKUKUNDA KÖLELIKK}

Kölelik, diğer pek çok toplumda olduğu gibi İslam toplumunda ve dolayısıyla Osmanlı Devleti'nde kendisine yer bulan bir kurum olmuştur. Bir İslam devleti olarak Osmanlı'da kölelik, doğaldır ki İslam hukukunun kurallarıyla çerçevelenmiş durumdadır. İslamiyet'in gelmesinden önce Arap toplumları arasında yaygın şekilde kullanılan bu kurumda köleler insanlarla bir tutulmadığı gibi adeta bir mal statüsünde görülmüş, kölelere karşı efendileri tarafından yapılacak her türlü muameleye göz yumulmuş, efendilerin kölelerini istedikleri zaman öldürebilmeleri dahi olağan karşılanmıştır.

İslamiyet ise toplum içinde bu denli geniş yer bulan bu kurumu, aşağıda değinilecek sebeplerle tamamen ortadan kaldırma yoluna gitmemiş; ancak belirli şartlara tabi tutarak kölelerin haklarının iyileştirilmesi ve bir bakıma aşamalı olarak köleliğin sona ermesine yol açacak bir düzene geçilmesini hedeflemiştir ${ }^{5}$. İslamiyet, bu hedefine ulaşabilmek için kurumu temelden

4 Çağatay, Neșet (1957) İslam'dan Önce Arap Tarihi ve Cahiliye Çağı, Ankara, Ankara Üniversitesi İlahiyat Fakültesi Yayınları, s. 119-120.

5 Aydın/Hamidullah, s.238; Akgündüz, Ahmed (1997) İslam Hukukunda Kölelik-Cariyelik Müessesesi ve Osmanlı'da Harem, 4.Baskı, İstanbul, Osmanlı Araştırmaları Vakfı, s. 138. 
etkileyecek değişiklikler yapmıştır. Bu değişikliklerden en çok etkilenenler ise köleliğin meydana gelme sebepleri ve sona erme yolları olmuştur.

\section{A. KÖLELİĞİN SEBEPLERİ}

Cahiliye dönemi Arap toplumunda köleliğin sebeplerinin oldukça çeşitli olduğu görülür. Bunlar arasında kişinin ödeyemediği borçları nedeniyle kendisini veya çocuklarını köle olarak satması, işlediği ağır bir suç nedeniyle ceza olarak köle statüsüne sokulması ve korsanlık faaliyetleri nedeniyle köle haline getirilmesi sayılabilir ${ }^{6}$. Köle haline gelmek için bu denli fazla yolun bulunması, toplumda köleliğin de bir hayli yaygın olması sonucunu doğurmuştur. İslamiyet ise anılan bu çeşitli kölelik sebeplerini oldukça kısıtlamış ve içlerinden sadece iki hali benimsemiştir ki bunlar; köle anneden doğma ve savaşta esir düşmedir. Böylelikle İslam, kölelik sebeplerini azaltmakla toplumdaki köle sayısının giderek azalması hedefine ulaşma yolunda da önemli bir adım atmış olmaktadır'.

\section{Köle Anneden Doğma}

Köleliğin doğal sebebi, köle olarak doğmaktır. İslam hukukunda kölelik, annenin statüsüne tabidir ${ }^{9}$. Bu nedenle kural olarak köle annelerden doğan çocuklar da köle olur. Köleliğin belirlenmesinde babanın statüsü dikkate alınmaz. Dolayısıyla hür bir babayla köle bir anneden doğan çocuk da yine köle

6 Akyılmaz, Gül (2004) “Osmanlı Hukukunda Köleliğin Sona Ermesi ile İlgili Düzenlemeler ve Tanzimat Fermanı'nın İlanından Sonra Kölelik Müessesesi”, Gazi Üniversitesi Hukuk Fakültesi Dergisi, C:9, S:1-2, s. 215; Ceylan, Metin (2018) İslam Hukukunda Kölelik, Ankara, Adalet Yayınevi, s. 43.

7 Diğer taraftan, kimi kaynaklarda İslam hukukunda tek bir kölelik sebebi bulunduğu, bunun da savaşta esir düşme olduğu; diğer sebep olarak anılan köle anneden doğmanın ise ilk sebebin bir uzantısı olduğu ifade edilmektedir. Bkz. Akgündüz, s. 119; Cin, Halil/Akgündüz Ahmed (2011) Türk Hukuk Tarihi, İstanbul, Osmanlı Araştırmaları Vakfı, s. 456-457; Aydın, M. Akif (2012) Türk Hukuk Tarihi, 9.Baskı, İstanbul, Beta, s. 236.

8 Siska, Katalin (2016) "Slavery in the Ottoman Empire", Journal on European History of Law, C:7, S:2, s. 73.

9 Aydın/Hamidullah, s. 239. 
olarak doğmuş olacak; bunun aksine, hür bir anneden doğan çocuk ise babası köle dahi olsa hür olacaktır.

Anılan kuralın tek istisnasını efendilerin cariyelerinden ${ }^{10}$ doğan çocukları oluşturur. Efendilerin cariyelerinden olan çocukları, her ne kadar anneleri köle olsa dahi, hür olarak doğmuş kabul edilir. Bunun için efendinin çocuğun kendisinden olduğunu kabul ederek tanımış olması gerekir. Aksi halde, doğacak çocuk köle statüsünde kalacaktır ${ }^{11}$.

\section{Savaşta Esir Düşme}

Köleliği yaygınlaştıran ve varlığını devam ettirmesine neden olan temel sebep, savaşta esir düşmektir. Savaşta esir düşmenin, köleliğin tarihsel süreçte ortaya çıkmasının da asıl sebebi olduğu kabul edilmektedir ${ }^{12}$. Buna göre, kazanılan bir savaş sonunda ele geçirilen esirlerin doğrudan öldürülmeleri dışında kalan seçenekler karşılıklı ya da karşılıksız salıverilmeleri ya da köle olarak kullanılmalarıdır. Karşılıksız salıverilme galip taraf için hiçbir kazanımı olmadığından; fidye karşılığı salıverilme de yenilen devletin maddi durumunun uygun olmaması gibi sebeplerle her zaman mümkün olmayabileceğinden uygulamada pek sık görülen yöntemler olmamıştır. Bu durumda savaş esirlerini köle olarak kullanma; öldürmenin alternatifi olarak karşımıza çıkmakta ve aslında esirlerin hayatının korunması amacını gütmektedir.

Kural olarak İslam'da esas olan sulh halidir ve savaşa ancak zaruri hallerde başvurulabiliri ${ }^{13}$. Yine de ister kendisi tarafından başlatılsın, isterse bir saldırıya maruz kalsın, İslam toplumunun her an bir savaşın içinde bulunması olasıdır ve bu savaşlardan galip çıkabilmek için İslam hukuku, savaşa ve savaş

10 Sözlükte 'para ile satın alınan halayık/ harpte esir düşmüş veya odalık olarak alınmış kız' anlamlarında gelen cariye kelimesi, dilimizde kadın köleler için özel olarak kullanılan bir terimdir. Bkz. Devellioğlu, Ferit (2015) Osmanlıca-Türkçe Ansiklopedik Lügat, Ankara, Aydın Kitabevi, s. 142; Aydın/Hamidullah, s. 237.

11 Üçok, Coşkun/Mumcu, Ahmet/Bozkurt, Gülnihal (2016) Türk Hukuk Tarihi, 18.Baskı, Ankara, Turhan Kitabevi, s. 108; Cin, Halil/Akyılmaz, Gül (2014) Türk Hukuk Tarihi, 5.Baskı, Konya, Sayram Yayınları, s. 314.

12 Bozkurt, s. 66-67.

13 Özel, Ahmed (1984) İslam Hukukunda Ülke Kavramı, İstanbul, Marifet Yayınları, s. 41,49. 
esirlerine dair çeşitli hükümler getirmek durumunda kalmıştır. Bu doğrultuda İslamiyet'in köleliği ortadan kaldırmamasının asıl sebebinin de, köleliğin ölüme alternatif olması nedeniyle, savaş esirlerinin hayatını koruma altına almak olduğu ileri sürülmektedir ${ }^{14}$.

İslam hukukunun temel kaynağı olan Kur'an'da savaş esnasında kafirlerin etkisiz hale getirilince esir alınması, daha sonra da bunların karşılıksız ya da fidye karşılığ 1 salıverilmesi gerektiği belirtilmektedir ${ }^{15}$. Esirlerin köle haline getirilmesine dair ise Kur'an'da herhangi bir hüküm bulunmamaktadır. Bu uygulama, kaynağını dönemin uluslararası hukuk teamüllerinden almıştı1 ${ }^{16}$. Dönemin teamülleri gereğince diğer devletlerin genelinin bu yola başvurması, İslam devletini de bu yönteme itmiştir. Bu sayede, köle haline getirmenin uygulanmaması durumunda yukarıda anılan olumsuz sonuçların doğmasından da kaçınılmış olunacaktır. İslam devlet başkanı kamu yararı ilkesi gereğince bu konuda karar verme yetkisini haizdir ${ }^{17}$.

İslam hukuku alimlerince savaşta esir düşenlerin köle olarak kullanılması 'ganimet' kavramına dayandırılarak açıklanmıştır. Ganimet, İslam hukukuna göre 'Müslümanların savaş yoluyla gayrimüslimlerden ele geçirdikleri esirler ve her türlü mal' demektir ${ }^{18}$. Buna göre, kazanılan bir savaş sonucunda ele geçirilen gayrimüslim kişiler ganimet kapsamında köle olarak Müslümanlara ait olmaktadır. Müslüman esirlerin köle yapılması ise söz konusu değildir ${ }^{19}$.

14 Aydın/Hamidullah, s. 238; Aydın, s. 234; Parlatır, İsmail (1983) “Türk Sosyal Hayatında Kölelik", Belleten, C:47, S:187, s. 811.

15 "Nihayet onları çökertip etkisiz hale getirdiğinizde bağı sıkı bağlayın (sağ kalanlarını esir alın). Artık bundan sonra (esirleri) ya karşlıksız ya da fidye karşılığı salıverin.” Muhammed $47 / 4$.

16 Özel, Ahmet (1996) İslam Devletler Hukukunda Savaş Esirleri, Ankara, Türkiye Diyanet Vakfi Yayınları, s. 87.

17 Akyılmaz, s. 219; Engin, Nihat (1992) “Osmanlı Devletinde Kölelik” (Doktora), Marmara Üniversitesi, Sosyal Bilimler Enstitüsü, s. 35; Aydın, s. 236.

Erkal, Mehmet (1996) “Ganimet”, TDV İslam Ansiklopedisi, C:13, İstanbul, s. 351.

19 Aydın/Hamidullah, s. 239; Aydın, s. 236. Ne var ki kişinin, esir alındıktan sonra henüz köleleştirilmeden Müslüman olması, köle haline getirilmesini engellemeyecektir. Bkz. Özel, s. 63 . 
Savaş sırasında elde edilen ganimetlerin hangi yönde kullanılabileceği Kur'an'da ayrıntılı olarak belirlenmiştir. Buna göre, ganimetlerin beşte biri Allah'a, Peygamber'e, onun yakınlarına, yetimlere, yoksullara ve yolculara; geri kalan beşte dördü ise savaşa katılmış bulunan askerlere aittir ${ }^{20}$.

Savaşa katılmış askerlere ait olan beşte dörtlük kısmın kimlere ne oranda dağıtılacağı meselesi ise fakihler arasında tartışma konusu olmuştur. Payın dağıtılacağı kişilerin kapsamı konusundaki hakim görüş, ganimetten pay alacakların Müslüman, hür ve tam ehliyetli olması gerektiğidir. Bu doğrultuda, Müslümanların yanında savaşa katılsa dahi gayrimüslimlerin, kölelerin, kadın ve çocukların ganimete hak kazanmaları mümkün görülmemiştir. Ancak bu kimselere savaşta gösterdikleri yarar karşılığında bir miktar hediye verilmesi uygun bulunmuştur ${ }^{21}$.

Payların hangi oranda dağıtılacağı meselesinde de Ebu Hanife, savaşa atlı olarak gelenlere iki, yaya olarak gelenlere bir pay verilmesi gerektiğini kabul ederken; Ebu Yusuf, İmam Muhammed ve fakihlerin çoğunluğuna göre atlılara üç; yayalara bir pay verilmesi gereklidir ${ }^{22}$.

Ganimetin beşte birlik kısmının ise uygulamada doğrudan devlet hazinesine aktarılarak devlet başkanının tasarrufuna bırakıldığı ve onun gerekli gördüğü alanlarda bu kısmı harcama yetkisinin tanındığı görülmüştür.

İslam hukukunda köleliğe ilişkin anılan genel açılamalardan sonra Osmanlı Devleti’ne bakıldığında, köleliğin burada ortaya çıkışının da benzer şekilde savaş esirliğinden kaynaklandığı görülür. Devletin kurucusu Osman Bey'den itibaren Bizans ile girişilen savaşlarda birtakım esirlerin ele geçirildiği bilinmesine rağmen, bunlara ne şekilde muamele edildiği kaynaklarda açıkça yer almamaktadır. Ancak Osman Bey’in komşu devletlerle dostça geçinmeyi tercih eden sözleri devletin ilk yıllarında savaş esirlerini köle olarak almaya pek yanaşmadığının göstergesi sayılı²3. Aynı uygulama Orhan Gazi döneminde de devam etmiştir. Böylece I. Murad devrine kadar savaşlardan elde edilen esirlerin köle olarak kullanılmasının pek tercih edilmediği, diğer bir deyişle

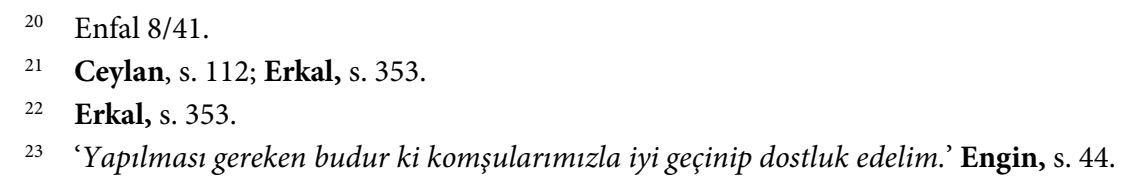


yerel halka çok fazla müdahale edilmediği ve bu sayede genellikle gayrimüslimlerden oluşan halkın yeni kurulan devlete alışmasına kolaylık sağlandığı söylenebilecektir ${ }^{24}$.

I. Murad dönemine gelindiğinde ise girişilen başarılı savaşların sonucunda ülke topraklarının hızla genişlemesi, yeni ele geçirilen bu yerlerin imarında ve işlenmesinde savaş esirlerinin kullanımı ihtiyacını doğurmuş ve bu ihtiyaç da, Osmanlı'da köleliğin ortaya çıkmasının temel sebebi olmuştur ${ }^{25}$. Diğer taraftan, giderek artan savaşlar sonunda çok sayıda savaş esirinin ele geçirilmesi, esirlere ne şekilde muamele edilmesi gerektiği meselesini de beraberinde getirmiştir. Bu meseleye çözüm; savaşlarda ele geçen ganimetlerin bește birinin Kur'an'ın ilgili ayetinde geçen kişilere paylaştırılmak üzere devlet hazinesine aktarılması usulünün Osmanlı Devleti'nde de uygulanmaya başlanmasıyla bulunmuştur ${ }^{26}$. Böylece elde edilen savaş esirleri köle statüsüne geçirilmeye başlanmış; bunlardan beşte biri devlete aktarılmış, geri kalan esirler de savaşa katılan askerlere ganimet olarak dağıtılmıştır. Devlete ait olan bu beşte birlik kısım için Farsça 'beşte bir' anlamına gelen 'penç-yek' kelimesi kullanılmaya başlanmış ve zamanla bu kavram 'pençik usulü’ olarak ifade edilir olmuştur $^{27}$. I. Murad devrinde başlayan bu pençik uygulaması, Osmanlı Devleti'nde kölelik kurumunun dayanağını oluşturmuştur. 1402 yılındaki Ankara Savaşı'nın ardından girilen Fetret Devri itibariyle ise yeni fetihlerin yapılamıyor oluşu, ganimet kapsamında köle elde edilmesini de olanaksız kılmış ve bu durum devletin asker temininde ciddi bir açığa sebebiyet vermiştir. Bu açığı kapatmak adına yenilikçi bir adım atılarak, Hristiyan zimmi çocukların belirli kurallar altında 'devşirilmesi' usulü getirilmiştir. Fatih Sultan Mehmet devrinde esas şeklini alan ve 'Kul Sistemi' olarak adlandırılan bu kurum ile

24 Tahiroğlu, Bülent (1981) "Osmanlı İmparatorluğunda Kölelik”, İstanbul Üniversitesi Hukuk Fakültesi Mecmuası, C:45, S:1-4, s. 652. Engin, Nihat (2002) “Osmanlılar'da Kölelik”, TDV İslam Ansiklopedisi, C:26, İstanbul, s.246. Bununla birlikte, Orhan Gazi döneminde savaşlardan ele geçirilen esirlerin köle pazarında satıldığına dair bilgiler, adı geçen padişah döneminden itibaren ülkede esir ticaretinin başladığını göstermektedir. Engin (1992), s. 57. Engin (1992), s. 62.

26 Akgündüz, s. 192, 198; Ceylan, s. 80-81; Yiğit, Ahmet (2015) “XVI. Yüzy1l Edirne’sinde Köle ve Cariyeler", Asia Minor Studies, C:3, S:5, s. 151.

27 Özcan, Abdülkadir (2007) "Pencik”, TDV İslam Ansiklopedisi, C:34, İstanbul, s. 226. 
birlikte devşirilerek köle haline getirilen kişiler sadece askeri amaçlarla kullanılmakla kalmamış; devletin yönetim kademesinde de kendilerinden yararlanılmaya başlanmıştır. ${ }^{28}$ Öyle ki zamanla Osmanlı'da ilmiye sınıfı mensupları hariç olmak üzere üst düzey devlet yöneticilerinin neredeyse tamamının devşirmelerden oluştuğu görülmüştür ${ }^{29}$.

Osmanlı Devleti kölelere, İslam hukukunun öngördügü şekilde iyi davranmış, kölelerin haklarını korumaya özen göstermiş, böylece Osmanlı Devleti'nde yaşayan köleler çağdaşı pek çok toplumdaki kölelerden daha iyi şartlarda hayatlarını sürdürmüşlerdir ${ }^{30}$.

\section{B. KÖLELİĞİN TEDBİR DIŞINDAKİ SONA ERME YÖNTEMLERİ}

İslam hukuku, aşamalı olarak ortadan kaldırılması amacını taşıdığından, köleliğin sona ermesine yol açacak pek çok yöntem öngörmüş ve bunların uygulanmasını teşvik etmiştir. İslam’a göre kölelerin özgürlügüne kavuşturulması adeta bir ibadettir ${ }^{31}$.

28 Üçok/Mumcu/Bozkurt, s. 211; Karataş, Abdullah Vefa (2020) “Türk Hukuk Tarihi Açısından Kul Sistemi”, Yıldırım Beyazıt Hukuk Dergisi, Y:5, S:1, s. 159. Ne var ki aslında özgür olan zimmi çocukların köle haline getirilmesi esasına dayanan kul sisteminin İslam hukukunun kölelikle ilgili hükümlerine aykırı olduğu meselesi uzun tartışmaları beraberinde getirmiş ve konuyla ilgili neredeyse tüm eserlerde bu kurumun İslam hukuku kurallarıyla uyumlu olup olmadığı sorgulanagelmiştir.

29 Öztürk, Yücel (2017) “Osmanlı İmparatorluğu'nda Köle Emeğinin Rolü ve Hacmi”: Yağc1, Zübeyde Güneş/Yaşa, Fırat (Editörler), Osmanlı Devleti’nde Kölelik, İstanbul, Tezkire Yayıncilık, s. 32.

30 Akyılmaz, s. 221; Ekinci, Ekrem Buğra (2014) Osmanlı Hukuku, 3. Baskı, İstanbul, Arı Sanat Yayınları, s. 431; Ekin, Ümit (2017) "Seyahatnamelerin Ișığında Osmanlı Toplumunda Köleler”: Yağcı, Zübeyde Güneş/Yaşa, Fırat (Editörler), Osmanlı Devleti’nde Kölelik, İstanbul, Tezkire Yayıncilık, s. 201.

31 Fendoğlu, Hasan Tahsin (1996) İslam ve Osmanlı Hukukunda Kölelik ve Cariyelik, İstanbul, Beyan, s. 196. 


\section{Gönüllü Azat (Itk)}

Köleliği sona erdiren en tabii yol, efendinin kölesini gönüllü olarak özgürlüğüne kavuşturmasıdır. Bu kavram fikıhta genellikle ıtk kelimesiyle karşılığını bulur ${ }^{32}$. Burada efendi, hiçbir karşılık beklemeden, tek taraflı bir irade beyanıyla kölesini azat etmektedir. İslam kaynaklarında gönüllü azat sıklıkla tavsiye edilmiştir ${ }^{33}$.

Gönüllü azat, tek taraflı irade beyanıyla gerçekleşeceğinden, ne kölenin kabul beyanına ne de başka bir işleme ihtiyaç duyar. Yine de uygulamada köle azatının ispat edilebilmesi için bu işlemin iki şahit huzurunda yapıldığı ve hatta mahkeme önüne gidilerek kadı kararıyla azatın tescil edildiği görülmüştür ${ }^{34}$. Kölelerin hangi yaşta azat edileceklerine dair herhangi bir sınırlama bulunmamakla birlikte, genellikle henüz gençken ve kendi hayatlarını idame edebilecek güçleri varken azat edildikleri kaynaklara yansımaktadır ${ }^{35}$.

32 Üçok/Mumcu/Bozkurt, s. 108.

33 "Asıl iyilik...mala olan sevgilerine rağmen onu...özgürlükleri için kölelere verenlerin...dir." Bakara 2/177; “O (sarp yokuş) köle azat etmektir.” Beled 90/12. Hz. Peygamber de “...kim Müslüman bir köleyi azatlarsa o köle o kimsenin cehennem ateşinden kurtuluşuna vesile olur” demiştir. İbn Mace, Ebu Abdullah Muhammed b. Yezid el-Kazvini (2012) Sünen-i İbn Mace, C:7, İstanbul, Kahraman Yayınları, (Çeviren: Hatipoğlu, Haydar), s. 110.

Cin/Akyılmaz, s. 324. Örneğin, Osmanlı Devleti'nde Üsküdar Mahkemesi'nce verilen bir kararda Mahmut Çelebi isimli kişinin Rus asıllı erkek kölesini Allah rızası için azat ettiğini mahkeme huzurunda ikrar ettiği belirtilmektedir. Bkz. Yılmaz, Coşkun (Editör) (2010) İstanbul Kadı Sicilleri, Üsküdar Mahkemesi 51 numaralı sicil, C:8, İstanbul, İSAM Yayınları, Hüküm No.683, s. 326.

35 Karataş, Ali İhsan (2007) “Bursa Şer’iyye Sicilleri Işığında Osmanlı Devleti’nde Köleliğe Bir Bakış”, İSTEM, C:5, S:9, s. 144; Zilfi, Madeline C. (2018) Osmanlı İmparatorluğu’nda Kölelik ve Kadınlar, İstanbul, Türkiye İş Bankası Kültür Yayınları, s. 145. Diğer taraftan, Osmanlı Devleti’nde gönüllü köle azatının genellikle uzun yıllardır kendisinden istifade edilmiş, yaşı ilerlemiş ve artık ekonomik değeri düşmüş kölelere uygulandığına dair görüş için bkz. Ekin, s. 203. 


\section{Kitabet Akdi Yoluyla Azat}

Köle azat etmenin bir diğer yolu da onunla kitabet akdi yapmaktır. Kur'an'da da kitabet akdine yer verilmiş ve yapılması tavsiye edilmiştir ${ }^{36}$. Kitabet akdi kölelerin belirli bir bedel karşılığında özgürlüklerini kazanmak amacıyla efendileriyle sözleşme yapmaları olarak tanımlanabilir ${ }^{37}$. Tanımdan da anlaşılacağı üzere, burada köle ile kendisinin özgürlüğe kavuşması üzerine bir sözleşme yapılması söz konusudur. Efendi ile kölenin karşılıklı irade beyanlarıyla sözleşme kurulmuş olur. Burada köle kural olarak belirli bir edimi yerine getirmeyi; bunun karşılığında da efendi kölesini azat etmeyi taahhüt etmektedir. Kölenin yüklendiği edim belirli bir işi yerine getirme, belirli bir miktar bedeli ödeme ya da belirli bir süre boyunca çalışma olabilir ${ }^{38}$. Kölenin yüklendiği edim olarak belirli bir bedel kararlaştırılması halinde bunun peşin ya da taksitle ödenebileceği kabul edilmektedir ${ }^{39}$.

Sözleşmenin kurulmasından itibaren köle, sözleşme şartlarını yerine getirmek amacıyla çalışmaya hak kazanmış olacaktır. Bu süreçte efendi kölenin sözleşme hükümlerini yerine getirmesini engelleyecek davranışlarda bulunamayacaktır. Köle, bu andan itibaren kazandıklarını kendi hesabında tutabilecek ve zamanı geldiğinde efendisine ödeyerek özgürlüğünü satın alabilecektir. Kitabet akdi yapılmış kölelerin satımı ya da bağışlanması mümkün değildir. Kitabet akdi yapılmış cariyelerden efendilerin cinsel olarak yararlanması da uygun bulunmamaktadır ${ }^{40}$. Kitabet akdi iki tarafa borç

\footnotetext{
36 "Sahip olduğunuz kölelerden mükatebe yapmak isteyenlere gelince, eğer onlarda bir hayır görürseniz onlarla mükatebe yapın.” Nur 24/33.

37 Atar, Fahrettin (2006) "Mükatebe", TDV İslam Ansiklopedisi, C:31, İstanbul, s. 531.

38 Tahiroğlu, s. 667; Cin/Akyılmaz, s.324; Aydın, s. 241.

39 Örneğin Osmanlı Devleti'nde İstanbul Mahkemesi tarafından verilen bir kararda Hacı Behram isimli bir kişinin kölesiyle kitabet anlaşması yaptığı ve kitabet bedeli olan otuz bin akçenin ayda seksen akçe olmak üzere takside bağlandığı belirtilmektedir. Bkz. Yılmaz, Coşkun (Editör) (2019) İstanbul Kadı Sicilleri, İstanbul Mahkemesi 191 numaralı sicil, C:4, İstanbul, Kültür AŞ. Yayınları, Hüküm No.149, s. 167.
}

40 Ceylan, s. 201. 
yükleyen bir sözleşme olduğundan efendinin kitabet akdinden tek taraflı olarak cayabilmesi mümkün değildir ${ }^{41}$.

\section{Kefaret Olarak Azat}

İslam hukukunda kefaret 'dinin belirli yasaklarını ihlal eden kimsenin hem ceza hem de Allah’tan mağfiret dilemek maksadiyla yükümlü tutulduğu köle azat etme, oruç tutma, fakiri doyurma ve giydirme gibi mali veya bedeni nitelikli ibadetlerin genel adı' olarak tanımlanmaktadır ${ }^{42}$. Buna göre İslam dininin benimsemediği kimi hareketlerde bulunan kimselerin bunlara karşıllk olarak yerine getirmesi gereken eylemlerden biri de, köle azadıdır. $\mathrm{Bu}$ hareketlerin başında hataen adam öldürme, verilen yemini bozma ve zıhar gelmektedir.

Kur'an'a göre hataen adam öldürme halinde kişinin kefareti öncelikli olarak Müslüman bir köle azat etme olacaktır ${ }^{43}$. Benzer şekilde bilerek verdiği yemini tutmayan kimsenin kefareti de on fakiri doyurmak veya onları giydirmek ya da bir köle azat etmektir ${ }^{44}$. Kişi, sayılanlar arasından istediğini seçmekte serbest olsa da, köle azadının diğerlerine göre daha üstün olduğu, bu nedenle köle azat etmeye öncelik verilmesi gerektiği kabul edilmektedir". 'Kocanın, kendisine haram kılmak maksadıyla karısını veya karısının baş, yüz, sırt gibi bütünü ifade eden bir bölümünü evlenmesi dinen yasak olan yakını bir kadına benzetmesi ${ }^{36}$ olarak tanımlanan zıhar durumunda da karısına geri dönmek isteyen erkeğin öncelikle bir köle azat etmesi gerektiği Kur’an'da açıkça belirtilmiştiri ${ }^{47}$.

41 Fendoğlu, s. 216; Cin/Akyılmaz, s. 324. Buna karşılık kölenin kitabet aktinden cayabilmesi hususu ise fakihler arasında farklı görüşlere yol açmış, Hanefi ve Şafiiler kölenin cayabilmesinin mümkün olduğunu kabul etmişlerdir. Atar (2006), s. 533.

Yaran, Rahmi (2002) “Kefaret (Fıkıh)”, TDV İslam Ansiklopedisi, C:25, Ankara, s. 179.

Nisa 4/92 '...yanlışlıkla bir mümini öldüren kimsenin mümin bir köle âzat etmesi...gereklidir. ...Bunları bulamayan kimsenin Allah tarafından tövbesinin kabulü için iki ay peş peşe oruç tutması lazımdır.'

44 Maide 5/89.

45 Yaran, s. 180.

46 Yaman, Ahmet (2013) “Zıhar”, TDV İslam Ansiklopedisi, C:44, İstanbul, s. 387.

47 Mücadele 58/3. 


\section{4. Ümmü'l Veled Yoluyla Azad}

Efendisinden çocuk sahibi olan cariyeler için getirilmiş özel bir özgürlüğe kavuşma yolu da fikıhta 'istilad' olarak da geçen ümmü'l veled durumudur. Buna göre bir kadın köle, efendisinden çocuk sahibi olduğunda -efendinin bu çocuğun kendisinden olduğunu kabul etmesi şartıyla- ümmü'l veled konumuna geçer. Efendinin ölümüyle birlikte kendisi de doğrudan azat edilmiş olur. Doğan çocuğun kız ya da erkek olmasının bir önemi yoktur. Efendinin, çocuğun kendisinden olduğunu bir kere kabul etmesinden sonra artık köle kadın ümmü’l veled statüsüne geçer ve efendinin ölümüyle özgürlügüne kavuşacağı kesinleşir. Efendinin bu sözünden geri dönme hakkı yoktur ${ }^{48}$. Efendi, ümmü'l veled statüsündeki cariyesini satamaz, bağışlayamaz, rehnedemez ${ }^{49}$. Ancak mülkiyeti kendinde kalmak şartılla ümmü’l veled cariyesini başkasına kiralayabilir, kendi işlerinde çalıştırabilir ve hatta onu başkasıyla evlendirebilir ${ }^{50}$.

Ümmü'l veled ile ilgili bir istisnadan da bahsetmek gerekmektedir. Kural olarak köle anneden doğan çocuklar da köle olarak kabul edilmekle birlikte efendinin kendi cariyesinden olan çocuğu her ne kadar köle bir anneden doğmuş olsa da doğduğu andan itibaren hür olacaktır. Böylece normal şartlarda köle olarak doğacak ve tarihsel gelişim içerisinde kölelik kurumunun devam etmesinde payı olacak bir çocuk kendiliğinden özgür hale getirilmekte ve İslam hukukunun arzu ettiği şekilde köleliğin ortadan kaldırılmasına yönelik bir adım daha atılmış olmaktadır. Sonuçta ümmü’l veled kurumu sadece köle kadının kendisini değil, onun çocuğunu da kölelikten kurtararak etkisini daha da genişletmiş olmaktadır. Ümmü'l veled kadının başkasıyla evlendirilmesi durumunda bu evlilikten doğacak çocukların da annenin statüsüne tabi olduğu kabul edilmektedir. Buna göre, efendisi hayatta olduğu sürece kadın köle kalmaya devam edeceğinden, bu kadından doğan çocuklar da köle olarak

\footnotetext{
Üçok/Mumcu/Bozkurt, s. 127.
}

Cin/Akyılmaz, s. 325;

50 Merginani, Burhanüddin Ebu'l-Hasan Ali b. Ebu Bekir (2018) El-Hidaye Tercemesi, C:2, İstanbul, Kahraman Yayınları, (Çeviren: Meylani, Ahmed), s. 384 
doğacaklardır. Ancak efendinin ölümüyle kadın özgürlüğüne kavuşacağından artık çocukları da özgür olacaktır ${ }^{51}$.

\section{KÖLELIĞIIN SONA ERME YOLU OLARAK TEDBİR}

Köleliği sona erdirme yollarından biri olan tedbir, efendinin kendi ölümüne bağlı olarak kölesini azat etmesi anlamına gelmektedir ${ }^{52}$. Tedbir sözcüğü, Arapça ' $d b r$ ' kökünden gelir ve 'arka' anlamını taşır. Kişinin ölümünün hemen arkasından kölenin özgürlüğüne kavuşması nedeniyle, bu yönteme tedbir adı verilmiştir ${ }^{53}$. Burada kölesinin kendi ölümünden sonra azat edilmesini isteyen efendiye 'müdebbir'; azat edilecek olan köleye de 'müdebber' denir ${ }^{54}$.

Tedbirin kaynaklarına bakıldığı zaman, tedbir hakkında açık bir Kur’an ayetinin bulunmadığı görülür. Ancak, kişinin tek taraflı irade beyanıyla ve herhangi bir karşılık beklemeden bu yola başvurması aslında tedbirin bir nevi gönüllü azat olduğu yorumuna sebebiyet vermiştir. Kur'an'daki köle azadına ilişkin ayetlerle birlikte, ' ...hayır işleyin ki kurtuluşa eresiniz. ${ }^{55}$ ayetinde olduğu gibi hayır işlemenin övüldüğ̈ Kur'an ayetlerinin de tedbir için kaynak oluşturduğu kabul edilmiştir ${ }^{56}$. Anılan Kur'an hükümlerinin yanı sıra tedbir, esas kaynağını hadislerden ve icmadan almıştır ${ }^{57}$.

51 Fendoğlu, s. 228-229; Ceylan, s. 211. 'Zeyd, Amr'in azadsı ümm-i veledi olan Hind'i nikahla alıb Zeyd'in Hind'den oğlu olsa zikr olan veled hür olur mu? El-Cevab: Anası gibi olur, Amr fevt oldukta azad olur.' Akgündüz, Ahmed (2018) Şeyhü'l-İslam Ebüssu'ud Efendi Fetvaları, İstanbul, Osmanlı Araştırmaları Vakfı Yayınları, s. 251.

52 Atar, Fahreddin (2011) “Tedbir”, TDV İslam Ansiklopedisi, C:40, İstanbul, s. 258.

53 Akgündüz (1997), s. 136; İbn Kudame (2015) el-Muğni Muhtasarı, C:4, İstanbul, Karınca Polen Yayınları, (Çeviren: Tunçer, A. Alpaslan) s. 582. Ibn Mace, s. 93

Hac 22/77

Atar (2011), s. 258. Öyle ki, tedbirin kendi başına köleliği sona erdirmenin yollarından biri olmadığı, sadece gönüllü azatın bir türü olduğu da kabul edilmektedir. Bkz. Aydın, s. 240. Atar (2011), s. 258; İbn Kudame, s. 582. Kütüb-i sittenin tamaminda Hz. Muhammed'in müdebber kılınmış bir köleyi satmasına ilişkin hadisinin yer alması, tedbirin Sünnet kapsamındaki dayanağını oluşturmuştur. İlgili hadisin yer aldığı eserlere bir örnek için bkz. İbn Mace, s. 93-94. 


\section{A. TEDBİRIN KURULMASI}

Tedbir, efendi tarafından tek taraflı bir hukuki işlemle kurulur. $\mathrm{Bu}$ bakımdan bağış hükümlerine benzemektedir. Diğer taraftan tedbir işlemi, hükümlerini efendinin ölümüyle doğuracağından burada aslında bir vasiyetnamenin varlığından da söz edilebilir. Ancak tedbir işlemine aşağıda daha detaylı görüleceği üzere sıradan bir vasiyetnamenin ötesinde hükümler bağlandığından, tedbiri sadece bir vasiyetname olarak görmek uygun olmayacaktır. Tedbir, efendiyi bağlayıcı bir işlemdir. Vasiyetnamelerde, miras bırakanın istediği zaman vasiyetinden dönebileceği kuralının ${ }^{58}$ aksine, genel kabul gören görüşe göre efendi, bir kere tedbir işleminde bulunduktan sonra artık bundan dönemez ${ }^{59}$.

Tedbir işleminde bulunacak efendi, Müslüman ya da zimmi olabilir ${ }^{60}$. Hakim görüşe göre tedbirin geçerli olması için tedbir anlamını içeren sözlerin söylenmesi yeterli görülmüştür. Bu doğrultuda efendinin 'ben öldükten sonra hürsün' ya da 'ben seni müdebber kıldım' sözlerini ya da bu anlama gelecek benzer bir sözü söylemesiyle tedbir işlemi kurulmuş olur ${ }^{61}$. Uygulamada tedbiri kolaylaştırmak ve kapsamını genişletmek maksadıyla tedbir hükümlerinin daha geniş ve köleler lehine yorumlandığı görülmektedir. Örneğin bir kişinin ’sahip

58 Arı, Abdüsselam (2012) "Vasiyet”, TDV İslam Ansiklopedisi, C:42, İstanbul, s. 553.

59 Aydın, s. 240; Ceylan, s. 206. Ancak Şafii fakihler içinden bir kısmın, tedbiri vasiyetname hükümleri ile eş tutarak efendinin istediği zaman bundan dönebileceğini kabul ettikleri görülmektedir. Bkz. Fendoğlu, s. 222.

60 Kara Mihail v. Hristo adlı zimmi efendinin, Rus asıllı kölesi Yuvan v. Bahto’yu müdebber kılmasına dair kadı sicili için bkz. Yılmaz, Coşkun (Editör) (2019) İstanbul Kadı Sicilleri, Ahi Çelebi Mahkemesi 1 Numaralı sicil, İstanbul, Kültür AŞ Yayınları, Hüküm No.27, s. 66. Osmanlı Devleti uygulamasında zimmilerin köle sahibi olmalarının kimi dönemlerde yasaklandığı görülmektedir. Zimmilerin anılan örnekte de olduğu gibi kölelerine tedbir uygulamaları şüphesiz ki köle sahibi olmalarına izin verilen dönem bakımından söz konusudur. Zimmilerin köle sahibi olmalarının yasaklanmasına dair detaylı bilgi için bkz. Karataş, s. 139-141.

${ }^{61}$ Atar (2011), s. 258. Öyle ki efendinin ‘benim başıma bir iş gelirse özgürsün’ şeklindeki bir cümlesiyle de tedbirin kurulabileceği kabul edilmektedir. Zira 'başına bir iş gelmek' deyiminin adete göre ölmek anlamında kullanıldığı kabul edilmektedir. Bkz. Serahsi, Şemsü'l-eimme Ebu Sehl Ebu Bekir Muhammed b. Ahmed (2008) Mebsut, Akşit, Mustafa Cevat (Editör), İstanbul, Gümüşev Yayınları, s. 286. 
olduğum tüm kölelerim müdebberdir' şeklinde bir cümle sarf ettikten sonra yeni köle satın alması durumunda, her ne kadar tedbir iradesini oraya koyduğu andaki köleleri arasında bu yeni kölesi bulunmasa da kişinin ölümüyle, sonradan edindiği kölelerin de tedbir kapsamında özgür olacağı kabul edilmektedir ${ }^{62}$.

Tedbirin kurulması için herhangi bir şekil şartı bulunmamakla birlikte uygulamada tedbir işlemlerinin genellikle kadı huzurunda yapıldığı ve böylece sonradan ispatında güçlük yaşanmasının önüne geçilmek istendiği görülmektedir. Örneğin İstanbul'da yaşayan Hacce Amine Hatun adlı bir kimse mahkemeye giderek Rus asıllı cariyesi Mülayim'i mutlak tedbir ile müdebber kıldığını belirtmiştir ${ }^{63}$. Başka bir kararda ise Süleyman b. Abdüsselam isimli bir efendi, Gürcü asıllı kölesi Yusuf u mukayyed tedbirle müdebber kıldığını mahkeme huzurunda dile getirmektedir ${ }^{64}$.

Nitekim kurulurken kayıt altına alınmayan tedbirlerden dolayı efendinin ölümünün ardından kimi uyuşmazlıkların yaşanması mümkündür. Uygulamada da görüldüğü üzere, ölen efendinin mirasçıları, müdebber köleyi doğrudan terekenin bir parçası kabul edebilmekte, onun tedbire tabi olduğunu görmezden gelebilmektedir. Bunun üzerine kölenin, özgürlüğünün tespiti için kadıya başvurduğu ve delil olarak iki şahit getirmesiyle özgürlügünün tescil edildiği ve tereke mallarından ayrıldığ görülmektedir ${ }^{65}$.

Tedbirin tek taraflı bir hukuki işlem olmasından dolayı geçerliliği için kölenin rızası aranmaz. Tedbir işlemi kurulduğu andan itibaren, kölenin efendisinin ölümüyle özgürlüğüne kavuşacağı kesinleşir. Tedbir işleminin geçerli olması için efendinin tam ehliyetli olması gerektiği kabul edilmektedir.

62 Abdullah Efendi, Yenişehirli (2011) Behcetü'l-Fetava, Kaya, Süleyman/Algın, Betül/Trabzonlu, Zeynep/Erkan, Asuman (Hazırlayanlar), İstanbul, Klasik Yayınları, s. 147. Yılmaz, Coşkun (Editör) (2011) İstanbul Kadı Sicilleri, Bab Mahkemesi 3 numaralı sicil, İstanbul, İSAM Yayınları, Hüküm No.41, s. 114. terekenin bir parçası olarak görülmesinin üzerine mahkemeye başvurarak kendisinin mutlak tedbirle müdebber kılındığı ve bu nedenle terekeden ayrılmak istediğine dair mahkeme kaydı için bkz.: İstanbul Kadı Sicilleri, Ahi Çelebi Mahkemesi 1 numaralı sicil, Hüküm No.293, s.219 ve Hüküm No.512, s. 350. 
Buna göre ayırt etme gücüne sahip ve ergin olmuş kişiler tedbir işleminde bulunabileceklerdir ${ }^{66}$. Bu doğrultuda, henüz erginliğe ulaşmamış bir kişinin sahip olduğu kölesini müdebber kılması geçerli görülmemekte, eğer aynı niyeti devam ediyorsa erginliğe ulaştıktan sonra kölesi hakkında tekrar tedbir işlemi yapabileceği kabul edilmektedir ${ }^{67}$. Benzer şekilde henüz erginliğe ulaşmamış bir kişinin, 'ergin olunca sahip olacağım bütün kölelerim müdebberdir.' diyerek tedbir işlemi yapması da geçerli kabul edilmemektedir. ${ }^{68}$ Bununla birlikte, tedbir işlemini yaptıktan sonra efendinin temyiz kudretini yitirmesi tedbirin geçerliliğine etki etmez ${ }^{69}$.

Diğer taraftan, kişinin ikrah altında tedbir yoluna başvurmak zorunda kalması durumunda ise her ne kadar gerçek iradesi bu yönde olmasa da, böyle tedbirlerin geçerli olduğu kabul edilmektedir ${ }^{70}$. Görüldügü üzere köle lehine yorum ilkesi bir kere daha kendisini göstermektedir.

Tedbirin geçerli olabilmesi için efendinin, köle üzerinde mülkiyet hakkının bulunması gereklidir. Bazı durumlarda ise aynı köle üzerinde birden fazla kişinin mülkiyet hakkının bulunması söz konusu olabilir. Köle üzerindeki bu ortaklık, alelade kişiler arasında olabileceği gibi karı-kocanın köle üzerindeki ortak mülkiyeti şeklinde de ortaya çıkabilir ${ }^{71}$. Köle üzerinde ortak mülkiyet bulunması halinde, her bir ortak kendi payı oranında tedbir işleminde bulunabilecektir; ancak böyle bir durumda, yani üzerinde ortaklık bulunan köleye ilişkin olarak ortaklardan birinin tedbir yoluna gitmesi halinde, kölenin ne şekilde özgürlüğüne kavuşacağı meselesi, tedbirin bölünebilirliği konusundaki görüş ayrılıklarını da beraberinde getirmiştir.

Maliki, Şafii, Hanbeli hukukçular ile Hanefiler'den Ebu Yusuf ve İmam Muhammed köle azatlığının ve bunun bir uzantısı olarak tedbirin

$66 \quad$ Atar (2011), s.258; Serahsi, s. 291.

67 "Zeyd-i sağir cariyesi Hind'i tedbir-i mutlak ile tedbir eylese Zeyd baliğ oldukda Hind'i bey'a kadir olur mu? El-Cevab: Olur.” Feyzullah Efendi (2009) Fetava-yı Feyziye, Kaya, Süleyman (Hazırlayan), İstanbul, Klasik Yayınları, s. 102.

68 Serahsi, s. 291.

69 Serahsi, s. 294; Akgündüz (1997), s. 137.

70 İkrah-ı muteber ile olan tedbir şer'an sahih ve muteber olur mu? El-Cevab: Olur. Abdullah Efendi, s. 148.

71 “Zeyd, zevci Hind ile müşterek olduğu cariyeleri...” Akgündüz (2018), s. 248. 
bölünemeyeceğini savunmaktadır ${ }^{72}$. Buna göre, ortaklardan biri köleyi müdebber kıldığı zaman, o ortağın ölümüyle kölenin özgürlüğüne kavuşacağı kesinleşmiş olur. Diğer ortakların buna rıza göstermemelerinin bir önemi yoktur. Ancak doğaldır ki bir ortağın köleyi müdebber kılması, diğer ortaklar aleyhinde maddi zarara yol açacaktır. Diğer ortakların uğrayacakları bu zararı tazmin etmek de, köleyi müdebber kılan ortağa düşer. Hz. Muhammed’in 'Kim kendisiyle başkası arasında ortak bir köleyi hissesi oranında azad ederse onun vücudunun tamamını kölelikten kurtarmak da ona düşer.' sözü ve bu konudaki benzer diğer hadisler bu görüşün dayanağını oluşturmaktadır ${ }^{73}$.

Buna göre, ortaklardan biri köleyi müdebber kılmakla, kendi payı dışında kalan kölenin bedelini diğer ortaklara ödeme borcu altına da girmiş olmaktadır. Eğer ortağın, kölenin kalan bedelini tazmin edecek malı yoksa, köle yine tamamen müdebber olur; ancak bu sefer, Hz. Muhammed'in '...eğer yeterli malı yoksa...köle çalıştırılır'74 sözüne binaen özgürlüğüne kavuştuktan sonra çalışarak geriye kalan bedelin parasını çıkarmakla ve bunu diğer ortaklara ödemekle yükümlü kılınır ${ }^{75}$.

Köle azatllğının ve dolayısıyla tedbirin bölünebileceğini düşünen Ebu Hanife'ye göre ise ortaklardan birinin köleyi müdebber kılması durumunda, o ortağın ölümüyle birlikte köle sadece ortağın köle üzerindeki payı oranında azatlanmış olur ${ }^{76}$. Kalan miktar bakımından köle kalmaya devam edecektir. Diğer bir deyişle, pratik sonuç bakımdan kölelik statüsünde bir değişiklik yaşanmamış olacaktır. Böyle bir durumda diğer ortakların elinde çeşitli ihtimaller mevcuttur. Dilerlerse kendi payları açısından köleyi gönüllü azat edebilir ya da kendi payları oranında onlar da köleyi müdebber kılabilirler. Bu yollardan birine başvurmak istememeleri halinde, kölenin çalışarak azatlanmamış payının değerini kazanıp kendilerine ödemesini ve böylece kölenin özgürlüğüne kavuşmasını sağlayabilirler. Bu durumda köleyle kitabet

$\operatorname{Atar}$ (2011), s. 258; Fendoğlu, s. 240.

73 Ebu Davud, Süleyman b. Eş’as Es-Sicistani (2017) Sünen-i Ebu Davud, C:14, İstanbul, Şamil Yayınları, (Çeviren:Yeniel, Necati/Kayapınar, Hüseyin), s. 25-26.

74 Ebu Davud, s. 28-29.

75 Fendoğlu, s. 240.

76 Serahsi, s. 295. 
akti kurulmuş olacaktır ve köle mukatep köle statüsüne geçecektir. Son bir ihtimal de, köleye tedbir uygulayan ortağın yeterli parası varsa, diğer ortakların kölenin kalan bedelini bu ortaktan talep edebilmeleridir. Köleyi başta müdebber kılmış olan ortak dilerse ödediği bu meblağ için köleyle kitabet akdi kurabilir ve kölenin çalışıp bu bedeli kendisine vermesini isteyebilir ${ }^{77}$.

Ortaklık halinde tedbirin bölünebilmesine dair farklı iki görüş karşılaştırıldığında, ilk bakışta Ebu Hanife'nin görüşünün daha çok müdebbir lehine; Ebu Yusuf ve İmam Muhammed'in görüşlerinin ise müdebber köleler lehine olduğu söylenebilecektir. Zira ilk durumda köle her ne kadar müdebber olsa da diğer ortakların payları oranında köle kalmaya devam edecekken; ikinci görüşte köle bir kere müdebber kılındığı andan itibaren her halükarda özgürlüğüne kavuşacaktır. Ancak Ebu Hanife'nin görüşü daha detaylı incelendiğinde aslında burada tedbirin teşvik edilme amacının güdüldüğü görülebilecektir. $\mathrm{Bu}$ görüşte tedbir yoluna başvurulması, müdebbirler için herhangi bir yükümlülük getirmediğinden köle üzerindeki ortaklardan her biri dilediğince tedbir yoluna başvurabilecektir. Böylece diğer ortaklara da köleyi azat etme yönünde örnek teşkil etme ihtimalleri de doğmuş olacaktır.

Osmanlı Devleti uygulamasında köle üzerinde ortak mülkiyet bulunduğu hallerde ortaklardan birinin köleyi kendi payı oranında müdebber kılması halinde diğer ortakların kölenin kendilerine ait bedelini, eğer müdebbirin yeterli miktarda malı varsa, ona tazmin ettirebildiği görülmüştür ${ }^{78}$.

Tedbirin kurulması sırasında efendi isterse kölesine birtakım mallarını da vasiyet edebilir. Kural olarak kölelerin mülkiyet hakkı bulunmasa da, köleler efendilerinin ölümüyle özgürlüğe kavuşacaklarından, tedbir işlemi sırasında efendinin kölesine kimi mallarını bağışlaması mümkün kılınmıştır. Doğaldır ki köleler bu mallara efendinin ölümü üzerine özgür olduktan sonra sahip olabileceklerdir. Örneğin Mahmut Efendi isimli kişinin ölümünün ardından müdebber kölesi Hüsnügül Hanım, efendisinin tedbir işlemi sırasında kendisine bin kuruş vasiyet ettiğini ileri sürerek bu miktarı mirasçlardan talep etmiştir. Mirasçıların bu talebi reddetmeleri üzerine, iki şahit getirerek iddiasını

\footnotetext{
77 İbn Mace, s. 116-118.

78 Feyzullah Efendi, s. 102.
} 
ispat eden Hüsnügül Hanım'a mahkeme, murisin terekesinden bin kuruşun verilmesine hükmetmiştir ${ }^{79}$. Yine benzer başka bir kararda Fatma Hatun isimli bir efendinin, Ferah adındaki Rus asıllı kölesini mutlak tedbirle müdebber kıldığı ve kendisine döşek, yorgan, çarşaf vb. çeşitli ev eşyalarını ve kimi kıyafetlerini vasiyet ettiği belirtilerek, bu malların müdebbere verilmesine hükmedilmiştir. ${ }^{80}$

\section{B. TEDBİRIN ÇEŞITTLERİ}

Tedbir, müdebbirin ifadelerine göre dört farklı şekilde ortaya çıabilir. Bunlar; mutlak, mukayyed, muallak ve muzaf tedbirlerdir.

\section{Mutlak Tedbir}

Mutlak tedbir, efendinin tedbirin gerçekleşmesi için hiçbir şart koşmadığı tedbir türüdür. Doğaldır ki burada kastedilen, efendinin ölümü dışında ek bir şart konulmamasıdır. Örneğin efendinin 'ben öldükten sonra hürsün' şeklinde kuracağı bir cümle, içinde tedbirin mahiyeti gereği var olan ölüm şartı dışında başka hiçbir şart taşımadığından mutlak tedbir olarak nitelendirilecektir.

Diğer taraftan, efendinin kölesine belirli bir malını ya da mal varlığının belirli bir kısmını vasiyet etmesi halinin de kölesini mutlak tedbirle müdebber kıldığı anlamına geldiği kabul edilmektedir. ${ }^{81}$ Normal şartlar altında efendinin ölümünün ardından köleye herhangi bir mal ya da hisse kalması söz konusu olmayacak; bilakis köle, efendisinin terekesinin bir parçası olarak görülecektir. Kişi aynı anda terekenin hem parçası hem de hak sahibi olamayacağından, burada efendinin amacının aslında kölesini müdebber kılmak olduğu ileri sürülmüştür.

79 Yılmaz, Coşkun (Editör) (2019) İstanbul Kadı Sicilleri, Bab Mahkemesi 397 numaralı sicil, İstanbul, Kültür AŞ Yayınları, Hüküm No. 243, s. 191.

80 Yılmaz, Coşkun (Editör) (2011), Hüküm No.128, s. 169.

81 Bilmen, Ömer Nasuhi (1985) Hukukı İslamiyye ve Istılahatı Fıkhiyye Kamusu, C:4, İstanbul, Bilmen Yayınevi, s. 39. 


\section{Mukayyed Tedbir}

Tedbirin ikinci türü olan mukayyed tedbir ise kayıt altına alınmış; yani tedbir için ek bir şart koşulmuş olan tedbir demektir. Bu şartın efendinin ölümüne dair bir şart olması gerekiris2. Örneğin 'ben yakalandiğım bu hastalık sonucu ölürsem hürsün' şeklindeki bir tedbir iradesi, ölüme dair şart taşıdığından mukayyed tedbir olarak adlandırılacaktır. 'Hac yolunda ölürsem kölem azat olsun' beyanı da bir mukayyed tedbir örneğidir. Bu durumda efendinin hac yolunda ölmesi durumunda kölesi azat olacak, mirasçıların o köleyi kendi miras paylarına katmaları mümkün olmayacaktır ${ }^{83}$. Efendi, eğer tedbir beyanında belirtilen şekilde ölmezse, tedbir hüküm doğurmamış olacaktır. Efendinin sonradan başka bir sebeple ölmesi, yapılan tedbir işlemi açısından bir önem taşımaz.

Ölümün gerçekleşmesinin belli bir süreyle kayıt altına alınması hali de, mukayyed tedbir kapsamında değerlendirilmektedir. Örneğin 'ben beş yıl içinde ölürsem müdebbersin' şeklindeki bir tedbir beyanında efendinin beş yıl içinde ölmesi durumunda köle özgür olmuş olacaktır. Beş yılın ardından meydana gelecek bir ölüm ise kölenin statüsünü etkilemeyecektir. Diğer taraftan, efendinin ‘ben yüz yıl içinde ölürsem müdebbersin' gibi, ölümün gerçekleşmesi neredeyse mutlak olan bir süreyi tedbire şart kılması halinde ve kişinin yaşıtlarının da genellikle o kadar süre içinde zaten öldüğünün bilindiği durumda kölenin mukayyed değil; mutlak tedbirle müdebber olduğu kabul edilmektedir ${ }^{84}$. Zira kişi, anılan süre sonuna kadar her halükarda öleceğinden, artık tedbirin gerçekleşmeme ihtimali ortadan kalkmış olacak; yani aslında tedbire ek bir şart sürülmemiş olacaktır. Böyle durumlarda da mutlak tedbir hükümleri uygulanacaktır.

\section{Muallak Tedbir}

Bir diğer tedbir türü olan muallak tedbirde ise efendi kendi ölümüne değil; tedbir işlemine bir şart koşmaktadır. Efendinin koyduğu şart gerçekleştiği

\footnotetext{
Ceylan, s. 207.

Feyzullah Efendi, s. 705.

Merginani, s. 383.
} 
takdirde, köle özgürlüğüne kavuşacaktır. Örneğin 'şu işi yerine getirirsen müdebbersin' şeklindeki bir tedbir beyanı, tedbiri kölenin yerine getireceği bir işleme şart koştuğu için muallak tedbir olarak anılır. Burada köle, şartı yerine getirirse efendinin ölümünün ardından özgürlüğüne kavuşmuş olacaktır. Muallak tedbirde önemli olan husus, şartın efendinin ölümünden önce yerine getirilmiş olmasıdır ${ }^{85}$. Eğer köle efendinin sağlığında şartı yerine getirirse efendinin ölümüyle tedbir hükümlerini doğurmuş olur. Aksi halde, efendi öldüğünde eğer şart hala yerine getirilmemişse tedbir de hükümsüz kalacak; şartın efendinin ölümünden sonra yerine getirilmesi bir hüküm ifade etmeyecektir. Benzer şekilde, 'ölünceye dek bana sadakatle hizmet edersen müdebber ol' gibi bir beyan da muallak tedbir örneği teşkil etmektedir ${ }^{86}$. Kölenin, sahibine sadakatsizlik yapması durumunda özgürlüğüne kavuşması mümkün olmayacaktır.

Muallak tedbire konulacak şart, bir eylemin yerine getirilmemesi şeklinde olumsuz bir şart da olabilir. Bu durumda efendi ölünceye dek o eylem gerçekleşmezse köle efendinin ölümüyle özgürlügüne kavuşmuş olur. Örneğin, efendinin 'ben ölünceye kadar içki içmezsen müdebbersin' şeklinde, kölenin davranışına dair bir şart koyması durumunda muallak tedbir söz konusu olmaktadır. Eğer köle, efendinin ömrü süresince içki içerse şartı yerine getirmemiş olacağından tedbir işlemi de geçerliliğini yitirecektir ${ }^{87}$. Aksi durumda, efendinin ölümüyle özgürlüğüne kavuşacaktır.

\section{Muzaf Tedbir}

Tedbirin son çeşidi olan muzaf tedbir ise 'belli bir zamanın girmesi ya da çıkmasına bağlanan tedbir’ olarak tanımlanmaktadır ${ }^{88}$. Burada, tedbir işleminin sonuçlarını doğurması bir zamana bağlanmıştır. 'Cuma gününden itibaren müdebbersin’ cümlesi bir muzaf tedbir örneğidir. Bu durumda, ancak cuma gününden itibaren tedbir işlemi hükümlerini ifade etmeye başlayacaktır.

\footnotetext{
85 Bilmen, s. 39.

Ahmed Efendi, es-Seyyid/Ahmed el-Gedusi, es-Seyyid Hafız Mehmed (Derleyen) (2014) Neticetü’l Fetava, İstanbul, Klasik Yayınları, s. 93; Abdullah Efendi, s. 148. 
Anılan zaman gelmeden önce efendinin ölmesi durumunda köle özgürlüğüne kavuşamayacaktır. Söz konusu zamanın gelmesiyle birlikte ise artık köle müdebberdir, efendinin ölümüyle özgür hale gelir.

\section{TEDBİRINN HÜKÜMLERİ}

Tedbirin hükümleri, efendinin ölümü öncesinde ve sonrasında çeşitlilik göstermektedir. Konunun daha detaylı incelenebilmesi amacıyla, bu hükümleri iki ayrı başlık altında incelemek yerinde olacaktır.

\section{Efendinin Ölümünden Önce}

Efendinin ölümünden önce tedbirin hükümlerine bakıldığında ilk olarak söylenebilir ki müdebber kölelerin dahil olacakları hukuki işlemlerde diğer kölelerden farklı bir muameleye tabi tutulmaları söz konusu değildir ${ }^{89}$. Müdebber olsalar dahi, efendileri ölmediği sürece köle kalmaya devam edeceklerinden, bu köleler diğer kölelerin bağlı bulunduğu sınırlamalara tabidirler. Bu durumda müdebbir köleler, tıpkı diğerleri gibi efendilerinden izinsiz kendilerini borç altına sokacak hukuki işlemleri yapamayacaklar, ceza hukuku bakımından diyet ödenmesi gereken bir suç işlediklerinde diyetleri efendi tarafından ödenecek, haksız fiillerde de tazmin borcunu efendileri yerine getirecektir.

Tedbir işlemi bir kere kurulduktan sonra artık bundan dönülemeyeceği yukarıda belirtilmişti. Yine de kölelerin lehine olmak üzere bu kuralın istisnasının bulunduğu söylenebilir ki bu da, efendinin müdebber kıldığı kölesinin kendi ölümünden önce özgürlüğüne kavuşmasını istemesi halidir. Efendi bu amaçla kölesini gönüllü azat edebilir veya kölesiyle kitabet akdinde bulunabilir ${ }^{90}$. Her iki durumda da kölenin, tedbire nazaran daha kısa bir süre içinde özgürlügüne kavuşma ihtimali olmaktadır. Tedbirden vazgeçilememe kuralının genişletilmesinin asıl amacı da budur. Böyle bir durumda gönüllü azat edilen ya da kitabet akdinde bulunulan köle, henüz efendisi hayattayken

\footnotetext{
Ceylan, s. 207-208.

90 Atar (2011), s. 258. “Zeyd, müdebber eylediği cariyeyi azad eylese, azad olur mu? El-Cevab: Olur.” Akgündüz (2018), s. 248.
} 
dahi özgürlüğüne kavuşabilecek; onun ölümünü beklemek zorunda kalmayacaktır. Kitabet akti yapılan müdebber köle, eğer efendisinin sağlığında gerekli bedeli ödeyemezse, yine de efendinin ölümüyle birlikte tedbir hükümleri gereği özgürlüğüne kavuşmuş olacak; kitabet bedelini ödeme yükümlülüğünden de kurtulacaktır¹ .

Mülkiyeti kendisinde kalmak şartıyla efendi, müdebber kıldığ kölesinden yararlanmaya eskisi gibi devam edebilir. Bu doğrultuda kendi emrinde dilediği şsekilde çalıştırabileceği gibi isterse müdebber kölesini başkasına kiralayabilir. Aynı zamanda müdebber kölesini evlendirebilir, eğer cariyeyse ondan cinsel olarak yararlanmaya devam edebilir ${ }^{92}$. Bu açıdan müdebber kölelerin diğer kölelerden bir farkı bulunmamaktadır.

Efendinin müdebber kölesini mülkiyetinden çıkarıp çıkaramayacağı ya da yaygın karşılaşılan haliyle efendinin müdebber kölesini satıp satamayacağı meselesi mezhepler arasında fikir ayrilığına sebep olmuştur. Tedbir kurumunun varlığına da delalet gösterilen meşhur hadise göre Hz. Peygamber, bir kişinin müdebber kölesini satmış ve bedelini de kölenin eski sahibine vermiştiri3. Hanefi ve Malikiler, bu hadisi mukayyed müdebber köleler açısından yorumlamışlar ve mukayyed müdebber kölelerin satılabileceği; mutlak müdebber kölelerin ise satılamayacağına hükmetmişlerdir. Şafii ve Hanbeliler ise hadisi görünümüne göre yorumlayarak, ister mutlak ister mukayyed olsun her türlü müdebber kölenin satışının mümkün olduğunu kabul etmişlerdir ${ }^{44}$.

Mutlak müdebber kölelerin satılamayacağını kabul eden görüşe göre bu köleler, mülkiyetlerinin sahibinin elinden çıkmasına sebep olacak satış, bağışlama gibi bir işleme tabi tutulamayacak; ama tedbir, mutlak dışındaki diğer üç çeşitten biriyle kurulmuşsa bu durumda efendinin isteğiyle köle satılabilecek ya da başka bir yolla mülkiyeti elden çıkarılabilecektir. Osmanlı

\footnotetext{
91 Serahsi, s. 307.

92 Serahsi, s. 290; Müdebber kölenin, kendisini çalıștırmak isteyen efendisine karşı yapacağı itirazın kabul edilmeyeceğine dair bkz. Feyzullah Efendi, s. 102.

93 İbn Mace, s. 93. Bu hadis hakkında daha önce yapılan açıklama için bkz. dn. 57.

94 Merginani, s. 382; İbn Kudame, s. 583.
} 
Devleti uygulamasında da Hanefilerin görüşüne uygun olarak mutlak müdebber kölelerin mülkiyetinin elden çıkışı uygun bulunmamıştır ${ }^{95}$.

Tedbirin mutlak mı mukayyed mi olduğunun belli olmaması halinde ise, diğer bir deyişle efendinin kölesini müdebber kıldığı anda bunun hangi tür tedbir olduğunu belirtmemesi halinde tedbirin mutlak tedbir olduğuna hükmedileceği kabul edilmektedir ${ }^{96}$. Böylece o tedbire mutlak tedbir hükümleri uygulanacaktır. Mutlak tedbir hükümlerinin diğerlerine oranla kölenin daha lehine hükümler içermesi, bu yönde yorum yapılmasını uygun kılmıştır.

\section{Efendinin Ölümünden Sonra}

Efendinin ölümüyle birlikte müdebber kölenin özgürlüğüne hangi şartlar altında kavuşacağı meselesi de mezhepler arasında fikir ayrılıklarından bir diğerini oluşturmuştur. Şöyle ki, her ne kadar tedbirin vasiyetnameden ayrı bir işlem olduğu kabul edilse de, efendinin ölümünden sonra yürürlüğe gireceğinden ve tedbir gereği kişinin malvarlığında (ölümünden itibaren terekesinde) meydana gelecek azalma mirasçıları doğrudan etkileyeceğinden, kimi hukukçular tedbirin hükümlerini vasiyetname hükümlerine eş kılmışlar; bu kuralı da Hz. Peygamber'in 'müdebber...mirasın üçte birinden hürdür.' hadisine dayandırmışlardır ${ }^{97}$. Vasiyetnamelerin miras bırakanın dileğine uygun bir biçimde aynen uygulanabilmeleri için terekenin üçte birini geçmemesi gerekir $^{98}$. Tedbir için de aynı kural uyarınca, efendinin ölümü anındaki terekenin durumuna bakılacaktır. Eğer müdebber kölenin değeri, terekenin üçte birine eşit veya ondan daha az ise tıpkı vasiyetnamelerde olacağ tedbir işlemi de aynen uygulanabilecek ve köle, efendinin ölümü anında değerinin tamamından azat edilmiş olacaktır.

95 “Zeyd kulu Amr'ı tedbir'i mutlak ile tedbir ettikten sonra Zeyd Amr'ı Bekir'e hibe ve teslim eylese hibe-i mezbure sahiha olur mu? El-Cevab: Olmaz."; "Zeyd, tedbir-i mutlak ile tedbir ettiği kulu Amr’ı Bekir'e bey eylemek sahih olur mu? El-Cevab: Olmaz." Feyzullah Efendi, s. 102. Benzer yöndeki fetvalar için ayrıca bkz. Abdullah Efendi, s. 147.

96 Ebussuud Efendi (2013) Maruzat, (Hazırlayan: Düzenli, Pehlül), İstanbul, Klasik Yayınları, s. 215.

97 İbn Mace, s. 96; Merginani, s. 382.

98 Ar1, s. 553. 
Kölenin değerinin, efendinin terekesinin üçte birinden daha fazla olması durumunda ise kölenin özgürlügüne hangi oranda ve ne şekilde kavuşacağ tedbirin bölünebilmesi meselesiyle bağlantılı olarak çözüme kavuşturulmaktadır. Belirtmekte fayda vardır ki, kölenin değeri terekenin üçte birini aşıyor olsa dahi mirasçıların tümünün rıza göstermesi halinde, köle yine doğrudan özgürlügüne kavuşabilecektir ${ }^{99}$. Ancak mirasçıların bu yolu tercih etmemesi durumunda tedbirin bölünüp bölünememesi meselesi kendisini gösterecektir.

Tedbirin bölünemeyeceğini kabul edenlere göre, kölenin değeri terekenin üçte birinden fazla olsa dahi, köle efendinin ölümüyle özgürlüğüne kavuşmuş olur. Ancak üçte birden fazla olan değer için çalışması ve kazandığı parayı mirasçılara ödemesi gerekir ${ }^{100}$. Tedbirin bölünemeyeceğini kabul eden Ebu Hanife'ye göre ise böyle bir durumda köle sadece terekenin üçte biri kadarki kısımdan özgür olur. Değerinin geri kalanı için ise köle kalmaya devam edecektir. Ancak bu kısım için kendisine çalışma hakkı verilir. Böylece çalışarak kazandığı parayı mirasçılara verdiğinde özgürlügüne de kavuşmuş olur ${ }^{101}$. Yani bu görüşte de köle, ölmüş efendisinin isteğine uygun olarak yine özgürlüğünü elde edecektir; ancak değerinin artan kısmını çalışıp mirasçılara ödeyinceye kadar köle kalmaya devam edeceğinden, kölelik süresi uzamış olacaktır.

Kimi fakihler ise müdebberin değerinin terekenin üçte biriyle değil; tamamıyla karşılaştırılması gerektiğini ileri sürmüşlerdir ${ }^{102}$. Bu durumda kölenin değeri terekenin tamamının değerine eşit veya ondan azsa köle doğrudan özgürlüğüne kavuşmuş olacak, aksi halde kalan kısım için çalışma borcu altına girecektir. Bu görüşün kölelerin daha lehine olduğu söylenebilir.

Kölenin değerinin terekenin üçte birinden az ya da fazla olması dışında karşılaşılabilecek bir diğer ihtimal de, terekenin tamamen borca batık olması halidir. Terekeden alacaklıların payları ödendikten sonra geriye hiçbir miktarın kalmaması durumunda normal şartlarda köle de terekenin bir parçası olarak

99 Aydın/Hamidullah, s. 243.

$100 \operatorname{Atar}(2011)$, s. 259.

101 İbn Mace, s. 97.

102 Azınlıkta kalan bu görüşün sahipleriyle ilgili detaylı bilgi için bkz. İbn Mace, s. 97; Serahsi, s. 282; Fendoğlu, s. 225. 
alacaklıların paylarına karşılık onlara verilebilecek ya da satılıp onun bedelinden alacaklıların hakları ödenecektir. Müdebber kölelerin varlığı halinde ise bu köleler efendilerinin ölümü üzerine çalışarak değerlerinin karşılığını kazanmak ve bunu alacaklılara ödemek yükümlülüğü altına gireceklerdir ${ }^{103}$. Bu yükümlülüğü yerine getirmeleriyle birlikte de özgürlüklerini elde etmeleri kesinleşmiş olacaktır. Kölenin çalışıp değerini kazanmasına kadar geçen süre içinde kölelik halinin devam edip etmeyeceği fakihler arasında farklı hükme bağlanmıştır. Aralarında İmameyn'in de bulunduğu çoğunluğun görüşüne göre köle, efendinin ölümüyle özgürlüğünü kazanmış olacak; Ebu Hanife'ye göre çalışıp değerini ödeyinceye kadar köle kalmaya devam edecektir. Hatta bu ikinci görüsse göre, kölenin efendinin ölümü anından itibaren mükatep köle statüsüne geçtiği kabul edilmektedir ${ }^{104}$.

Tedbirin vasiyetnameden ayrılan bir diğer noktası, işte tam burada kendini göstermektedir. Terekenin borca batık olması durumunda normal şartlarda öncelik bu borçların ödenmesi olacağından vasiyetnamenin yerine getirilmesi mümkün olmayacaktır. Ancak burada İslam'ın amacına da uygun olarak kölelerin azat edilmelerine engel olmamak adına tereke borca batık olsa dahi, tedbirin her halükarda geçerli sayılacağı kabul edilmiştir. Alacaklıları maddi zarara uğratmamak için de özgürlügüne kavuşan ya da kavuşacak olan kölenin kendi bedelini kazanıp alacaklılara ödemesi usulü getirilmiştir. Görüldüğü üzere, burada her iki tarafin da menfaatlerinin korunması amaçlanmakta, bir yandan kölenin özgürlüğüne kavuşması garanti altına alınırken bir yandan da alacaklıların tedbir nedeniyle maddi zarara uğramaları engellenmiş olmaktadır.

Efendinin ölümünden sonra tedbirin doğuracağı hükümlerle ilgili olarak ele alınması gereken bir diğer konu da, müdebber kölenin çocuklarının durumudur. Kölelikte babanın değil, annenin durumu esas alındığından tedbir açısından da yine bu kurala paralel şekilde annenin durumuna bakılacaktır. Kural olarak müdebber kılınmış kadın kölenin çocuğu annesinin durumuna

103 Serahsi, s. 293-294.

104 İbn Mace, s. 97; Atar (2011), s. 259. “Zeyd, kulu Amr'ı Tedbir-i mutlak ile tedbir ettikten sonra düyunu terekesinden ezyed olduğu halde fevt olsa dainleri Amr'ı kıymetinde istis'aya kadir olurlar mı? El-Cevab: Olurlar.” Ahmed Efendi/Ahmed el-Gedusi (Derleyen), s. 94. 
tabi olur ${ }^{105}$. Buna göre, kadın kölelerin müdebber kılındıktan sonra doğuracağ çocukların da müdebber olacağı, efendinin ölümüyle annelerinin özgürlüğe kavuştuğu andan itibaren bu çocukların da kölelikten kurtulacakları kabul edilmektedir. Bu süreçte babanın özgür veya köle olmasının bir önemi bulunmaz $^{106}$. Kölenin müdebber kılındığı anda zaten var olan çocukları ise annelerinin bu durumundan yararlanamayacak ve köle kalmaya devam edeceklerdir ${ }^{107}$.

\section{TEDBİRIN SONA ERMESI}

Tedbirin doğal sona erme yolu, efendinin ölümünün ardından kölenin özgürlüğüne kavuşmasıdır. Ancak bu hal dışında tedbirin sona ermesine neden olacak kimi haller vardır ki bunların gerçekleşmesiyle tedbir işlemi ortadan kalkmış olacağından köle de özgürlüğüne kavuşamayarak köle kalmaya devam etmiş olacaktır. Bunlardan ilki, kölenin ölmesi halidir. Eğer ki müdebber köle henüz efendisi hayattayken ölürse tedbir işlemi de ortadan kalkacak ve köle özgür hale gelemeyecektir. Bu durumda kadın kölelerin çocukları da annelerine tabi olacaklarından, köle kalmaya devam edeceklerdir.

Bir diğer hal, efendinin sağlığında müdebber kölesini satması halidir. Yukarıda açıklandığı üzere, esas olarak mutlak tedbir dışında kalan bir yöntemle müdebber kılınmış köleler için kabul edilen satım halinde kölenin sahibi değişeceğinden, eski sahibinin uyguladığı tedbir işlemi de geçerliliğini yitirmiş olacaktır. Yeni sahibin köleyi müdebber kılması, elbette mümkündür.

Mutlak tedbir dışında kalan diğer hallerde efendinin koyduğu şartın gerçekleşmemesiyle de tedbir işlemi son bulabilecektir. Örneğin yakalandığı bir hastalıktan ötürü ölürse kölesinin müdebber olmasını isteyen bir efendi, o hastalıktan iyileştiği zaman tedbir işlemi de geçerliliğini yitirmiş olacaktır. Yine, ‘ölünceye dek bana sadakatle hizmet edersen müdebbersin’ ifadesiyle kölenin

\footnotetext{
105 Merginani, s. 364; Serahsi, s. 285.

106 Burada bahsedilen çocukların, kadın kölenin efendisi dışındaki birinden sahip olduğu çocuklar olduğu unutulmamalıdır. Zira daha önceden de belirtildiği üzere cariyelerin efendilerinden olan çocukları -efendilerinin onları kabul etmeleri şartıyla- doğdukları andan itibaren özgürdürler.
}

107 Bilmen, s. 41. 
muallak tedbir edilmesi halinde kölenin, efendisinin mallarını çaldığı anlaşıldığı an şartı yerine getirmediğinden tedbir de geçersiz hale gelmiş olacaktır ${ }^{108}$.

Müdebber kölenin, özgürlügüne bir an önce kavuşabilmesi için efendisinin ölümünü beklemek yerine onu öldürme yoluna gitmesi de karşılaşılabilecek bir diğer ihtimaldir. İslam hukukunda genel kural, kendisine vasiyetname bırakan kişinin ölümüne yol açan kimsenin o vasiyetten mahrum kalmasıdır ${ }^{109}$. Tedbiri vasiyetnameden ayıran bir diğer nokta da burada karşımıza çıkmaktadır. Müdebber köle, bir an önce özgürlüğüne kavuşmak için kendi efendisini öldürse dahi, hakim olan görüşe göre tedbirden mahrum bırakılmayacak ve efendisinin ölümüyle yine de özgürlügüne kavuşmuş olacaktır $^{110}$. Doğaldır ki köle, öldürme fiilinden dolayı yargılanabilecek ve gerekli cezaya çarptırılabilecektir ${ }^{111}$. Ancak bu yargılama, onun özgürlügüne kavuşmasına engel olmayacaktır. Anılan bu kuralın, İslam hukukunun amacına uygun olarak kölelerin mümkün olduğunca özgürlüğe kavuşmalarını sağlama ve bunun önüne geçmeme niyetinin bir sonucu olduğu görülmektedir. Efendisini öldürmeye çalışan kölenin eğer başarılı olamazsa onun yanında yaşamaya devam etmek zorunda olacağı açıktır. Ancak bu durumda efendinin artık bu köleye sahip olmak istemeyeceği ve onu elinden çıkarmak amacıyla satmaya çalışacağ müdebber kölelerin satılamayacağı kuralı, burada da kendisini gösterir. Eğer köle mutlak müdebber bir köleyse efendi, kölenin mülkiyetini elinden çıkarabilecek bir işlem yapamayacaktır ${ }^{112}$. Onun yerine efendilerin, böylesi

108 Abdullah Efendi, s. 148.

109 Ari, s. 554.

110 Ceylan, s. 210. Hanbeliler ise bu görüşe karşı çıarak, böyle bir durumda tedbirin batıl hale geleceğini kabul etmişlerdir. İbn Kudame, s. 584.

111 Nitekim Hz. Peygamber döneminde kendisine yakınlığıyla da bilinen Ümmü Varaka adlı bir kadın sahabi, sahip olduğu iki kölesini müdebber kılmış; köleler de özgürlüklerine erkenden kavuşmak amacıyla Ümmü Varaka’yı boğarak öldürmüşlerdir. Yapılan yargılama sonucu köleler ölüme mahkûm edilmiştir. Dayhan, Ahmet Tahir (2012) "Ümmü Varaka”, TDV İslam Ansiklopedisi, C:42, İstanbul, s. 332-333.

112 Akgündüz (2018), s. 248. Diğer taraftan, Hz. Ayşe'den rivayet edilen bir olaya göre kendisinin müdebber kıldığı bir kadın köle sonradan Hz. Ayşe’ye büyü yapmış, bunu da bir an önce özgür olabilmek amacıyla yaptığını itiraf etmiştir. Bu olay üzerine Hz. Ayşe kölesini 
köleleri kitabet akdi yapmaya mecbur bırakabilecekleri kabul edilmiştir ${ }^{113}$. Kölenin efendisini öldürmeyi başarması durumunda ise her ne kadar köle özgür olacaksa da, bu defa mirasçıların köleyi çalışmaya ve değerini kazanıp kendilerine ödemeye zorlayabilecekleri kabul edilmiştir ${ }^{14}$.

\section{SONUÇ}

Tedbir, köleliğin sona erme yöntemi olarak Osmanlı Devleti'nde oldukça sık başvurulan bir kurum olmuştur. Kurulabilmesi için efendi tarafından tek taraflı bir irade beyanının yeterli olması ve hükümlerini efendinin ölümünden sonra doğurduğundan efendinin sağlığında onu maddi açıdan etkilememesi, bu yola sıkça başvurulmasının nedenlerindendir.

Tedbirin kurulması aşamasında hukukçular arasındaki en derin tartışma, tedbirin bölünebilip bölünememesi noktasında kendini göstermiştir. Hâkim görüş, tedbirin bölünemeyeceği yönündedir. Böylece bir köle üzerinde birden fazla efendinin mülkiyet hakkı bulunduğu durumlarda bunlardan birinin tedbir yoluna başvurmasıyla kölenin sadece o efendinin payı oranında değil, değerinin tamamı oranında özgürlüğüne kavuşacağı uygun bulunmaktadır. Tedbirde bulunmayan efendilerin maddi açıdan zarara uğramamaları için de eğer imkân varsa tedbirde bulunan tarafın, yoksa da bizzat kölenin bu bedeli kendilerine ödemesi gerektiği kabul edilmiştir.

Kendisine tedbir yapılmış olan köle, efendisinin ölümüne kadar geçen sürede diğer kölelerden herhangi farklı bir muameleye tabi tutulmamaktadır. Ancak kölenin mülkiyetinin efendinin elinden çıkmasına sebep olacak hukuki işlemler, bu kuralın istisnasını oluşturmaktadır. Kölenin özgürlüğüne kavuşmasını efendinin ölümü dışında hiçbir ek şarta bağlı kılmayan mutlak tedbir hallerinde efendilerin kölelerini satamayacakları hakim görüşü oluşturmaktadır. Mutlak tedbir dışında kalan ve efendinin ölümünün yanında

üçüncü bir kişiye satmıştır. Hanefi fikhınca mutlak müdebber kölelerin satımı mümkün olmadığından, bu olayda adı geçen kölenin mukayyed müdebber bir köle olduğu kabul edilmektedir. Bkz. Serahsi, s. 283-284.

113 “Zeyd'in müdebber kulu Amr azad olmak için Zeyd'i katle kasd eylese Zeyd bey'e kadir olur mu? El-Cevab: Olmaz, kitabete kesmeye kadirdir.” Akgündüz (2018), s. 248.

114 Ceylan, s. 210. 
başka şartların da arandığı mukayyed, muallak ve muzaf tedbir hallerinde ise efendilerin müdebber kölelerini istedikleri zaman satabilecekleri kabul edilmektedir.

Efendinin ölümü üzerine kölelerin terekenin üçte birlik kısmı dahilinde özgür olacakları genel kabul edilen görüştür. Bu durumda kölenin değeri, efendinin terekesinin üçte birinden fazla ise ya da efendinin terekesi doğrudan borca batık durumda ise kölenin yine özgür hale geleceği; ancak terekeyi aşan kısım için çalışması ve bu bedeli mirasçılara ödemesi gerekliliği hakim görüştür.

Osmanlı Devleti'nde tedbir kurumu hakkında çok sayıda fetvanın ve mahkeme kararının bulunması, bu kurumun toplum içindeki yerini ve önemini gözler önüne sermektedir. Osmanlı'da tedbirle ilgili hukuki uyuşmazlıkların esas olarak, tedbirin gerçekten kurulmuş olup olmadığı noktasında ve çoğunlukla müdebberlerin iddiaları üzerine ortaya çıktığı görülmektedir. $\mathrm{Bu}$ gibi uyuşmazlıkları önlemek adına, her ne kadar böylesi bir zorunluluk bulunmasa da, efendiler tedbir işlemini doğrudan mahkeme huzurunda gerçekleştirmeye çalışmışlardır. Bunun yapılmadığı durumlarda ise efendinin ölümünün ardından mirasçılar ile müdebber köleler karşı karşıya gelmiştir. Böylesi davalarda genellikle müdebberlerin iki şahit getirerek iddialarını ispat etikleri ve özgürlüklerine kavuştukları görülmüştür.

Tedbir işlemiyle ilgili ortaya çıkan uyuşmazlıklarda her ne kadar farklı çözüm önerileri getirilmiş olsa da, temelde her zaman köle lehine yorum yapılmaya çalışıldığı görülmektedir. Kölelerin özgürlüğe kavuşturulmasını teşvik eden İslam hukuku, tedbir işleminin gerçekleştirilmesiyle efendileri tarafından özgürlüğe kavuşturulma yolunda önemli adım atılan kölelerin çeşitli sebeplerle bu imkanlarının ellerinden alınmasını önlemek istemiştir. Öyle ki, kendilerine tedbir yapan efendilerini öldürme yolunu seçen kölelerin dahi, haklarındaki tedbir hükümlerinin devam ettiği çoğunluk tarafından kabul edilmektedir. 


\section{KAYNAKÇA}

Abdullah Efendi, Yenişehirli (2011) Behcetü'l-Fetava, Kaya, Süleyman/Algın, Betül/Trabzonlu, Zeynep/Erkan, Asuman (Hazırlayanlar), İstanbul, Klasik Yayınları.

Akgündüz, Ahmed (1997) İslam Hukukunda Kölelik-Cariyelik Müessesesi ve Osmanlı'da Harem, 4.Baskı, İstanbul, Osmanlı Araştırmaları Vakfı.

Akgündüz, Ahmed (2018) Şeyhü'l-İslam Ebüssu'ud Efendi Fetvaları, İstanbul, Osmanlı Araştırmaları Vakfı Yayınları.

Akyılmaz, Gül (2004) “Osmanlı Hukukunda Köleliğin Sona Ermesi İle İlgili Düzenlemeler ve Tanzimat Fermanı’nın İlanından Sonra Kölelik Müessesesi”, Gazi Üniversitesi Hukuk Fakültesi Dergisi, C:9, S:1-2, s.213-238.

Arı, Abdüsselam (2012) "Vasiyet", TDV İslam Ansiklopedisi, C:42, İstanbul, s.552-555.

Atar, Fahrettin (2006) “Mükatebe”, TDV İslam Ansiklopedisi, C:31, İstanbul, s.531-533.

Atar, Fahreddin (2011) “Tedbir”, TDV İslam Ansiklopedisi, C:40, İstanbul, s.258-259.

Aydın, M. Akif (2012) Türk Hukuk Tarihi, 9.Baskı, İstanbul, Beta.

Aydın, M. Akif/Hamidullah Muhammed (2002) "Köle", TDV İslam Ansiklopedisi, C:26, İstanbul, s.237-246.

Bilmen, Ömer Nasuhi (1985) Hukukı İslamiyye ve Istılahatı Fıkhiyye Kamusu, C:4, İstanbul, Bilmen Yayınevi.

Bozkurt, Gülnihal (1981) "Eski Hukuk Sistemlerinde Kölelik", Ankara Üniversitesi Hukuk Fakültesi Dergisi, C:38, S:1, s.65-103.

Ceylan, Metin (2018) İslam Hukukunda Kölelik, Ankara, Adalet Yayınevi.

Cin, Halil/Akgündüz Ahmed (2011) Türk Hukuk Tarihi, İstanbul, Osmanlı Araştırmaları Vakfı. 
Cin, Halil/Akyılmaz, Gül (2014) Türk Hukuk Tarihi, 5.Baskı, Konya, Sayram Yayınları.

Çağatay, Neşet (1957) İslam'dan Önce Arap Tarihi ve Cahiliye Çağı, Ankara, Ankara Üniversitesi İlahiyat Fakültesi Yayınları.

Dayhan, Ahmet Tahir (2012) "Ümmü Varaka", TDV İslam Ansiklopedisi, C:42, İstanbul, s.332-333.

Devellioğlu, Ferit (2015) Osmanlıca-Türkçe Ansiklopedik Lügat, Ankara, Aydın Kitabevi.

Ebu Davud, Süleyman b. Eş’as Es-Sicistani (2017) Sünen-i Ebu Davud, C:14, İstanbul, Şamil Yayınları, (Çeviren: Yeniel, Necati/Kayapınar, Hüseyin).

Ebussuud Efendi (2013) Maruzat, (Hazırlayan: Düzenli, Pehlül), İstanbul, Klasik Yayınları.

Ekin, Ümit (2017) “Seyahatnamelerin Ișıı̆̆ında Osmanlı Toplumunda Köleler”: Yağcı, Zübeyde Güneş/Yaşa, Fırat (Editörler), Osmanlı Devleti’nde Kölelik, İstanbul, Tezkire Yayıncılık.

Ekinci, Ekrem Buğra (2014) Osmanlı Hukuku, 3. Baskı, İstanbul, Arı Sanat Yayınları.

Engin, Nihat (1992) “Osmanlı Devletinde Kölelik" (Doktora), Marmara Üniversitesi, Sosyal Bilimler Enstitüsü.

Engin, Nihat (2002)“'Osmanlılar'da Kölelik”, TDV İslam Ansiklopedisi, C:26, İstanbul, s.246-248.

Erkal, Mehmet (1996) “Ganimet”, TDV İslam Ansiklopedisi, C.13, İstanbul, s.351-354.

Fendoğlu, Hasan Tahsin (1996) İslam ve Osmanlı Hukukunda Kölelik ve Cariyelik, İstanbul, Beyan.

Feyzullah Efendi (2009) Fetava-yı Feyziye, Kaya, Süleyman (Hazırlayan), İstanbul, Klasik Yayınları.

İbn Kudame (2015) el-Muğni Muhtasarı, C:4, İstanbul, Karınca Polen Yayınları, (Çeviren: Tunçer, A. Alpaslan).

İbn Mace, Ebu Abdullah Muhammed b. Yezid el-Kazvini (2012) Sünen-i İbn Mace, C:7, İstanbul, Kahraman Yayınları, (Çeviren: Hatipoğlu, Haydar). 
Yılmaz, Coşkun (Editör) (2019) İstanbul Kadı Sicilleri, Ahi Çelebi Mahkemesi 1 numaralı sicil, İstanbul, Kültür AŞ Yayınları.

Yılmaz, Coşkun (Editör) (2011) İstanbul Kadı Sicilleri, Bab Mahkemesi 3 numaralı sicil, İstanbul, İSAM Yayınları.

Yılmaz, Coşkun (Editör) (2019) İstanbul Kadı Sicilleri, Bab Mahkemesi 397 numaralı sicil, İstanbul, Kültür AŞ Yayınları.

Yılmaz, Coşkun (Editör) (2019) İstanbul Kadı Sicilleri, İstanbul Mahkemesi 191 numaralı sicil, C:4, İstanbul, Kültür AŞ Yayınları.

Yılmaz, Coşkun (Editör) (2010) İstanbul Kadı Sicilleri, Üsküdar Mahkemesi 51 numaralı sicil, C:8, İstanbul, İSAM Yayınları.

Karataş, Abdullah Vefa (2020) “Türk Hukuk Tarihi Açısından Kul Sistemi”, Yıldırım Beyazıt Hukuk Dergisi, Y:5, S:1, s.153-188.

Karataş, Ali İhsan (2007) “Bursa Şer’iyye Sicilleri Işı̆ğında Osmanlı Devleti’nde Köleliğe Bir Bakış”, İSTEM, C: 5, S: 9, s.135-162.

Merginani, Burhanüddin Ebu'l-Hasan Ali b. Ebu Bekir (2018) El-Hidaye Tercemesi, C:2, İstanbul, Kahraman Yayınları, (Çeviren: Meylani, Ahmed).

Ahmed Efendi, es-Seyyid/Ahmed el-Gedusi, es-Seyyid Hafız Mehmed (Derleyen) (2014) Neticetü'l Fetava, İstanbul, Klasik Yayınları.

Özcan, Abdülkadir (2007) "Pencik”, TDV İslam Ansiklopedisi, C:34, İstanbul, s.226-228.

Özel, Ahmet (1996) İslam Devletler Hukukunda Savaş Esirleri, Ankara, Türkiye Diyanet Vakfı Yayınları.

Özel, Ahmed (1984) İslam Hukukunda Ülke Kavramı, İstanbul, Marifet Yayınları.

Öztürk, Yücel (2017) “Osmanlı İmparatorluğu’nda Köle Emeğinin Rolü ve Hacmi”: Yağcı, Zübeyde Güneş/Yaşa, Fırat (Editörler), Osmanlı Devleti'nde Kölelik, İstanbul, Tezkire Yayıncılık, s.31-56.

Parlatır, İsmail (1983) “Türk Sosyal Hayatında Kölelik”, Belleten, C: 47, S: 187, s.805-829. 
Serahsi, Şemsü'l-eimme Ebu Sehl Ebu Bekir Muhammed b. Ahmed (2008) Mebsut, Akşit, Mustafa Cevat (Editör), İstanbul, Gümüşev Yayınları.

Siska, Katalin (2016) "Slavery in the Ottoman Empire", Journal on European History of Law, C: 7, S: 2, s. 71-79.

Tahiroğlu, Bülent (1981) "Osmanlı İmparatorluğunda Kölelik", İstanbul Üniversitesi Hukuk Fakültesi Mecmuası, C: 45, S: 1-4, s. 649-676. Türkçe Sözlük (1983), Ankara, Türk Dil Kurumu Yayınları.

Üçok, Coşkun/Mumcu, Ahmet/Bozkurt, Gülnihal (2016) Türk Hukuk Tarihi, 18.Baskı, Ankara, Turhan Kitabevi.

Yaman, Ahmet (2013) “Zihar”, TDV İslam Ansiklopedisi, C: 44, İstanbul, s.387-390.

Yaran, Rahmi (2002) "Kefaret (Fıkıh)", TDV İslam Ansiklopedisi, C: 25, Ankara, s.179-182.

Yiğit, Ahmet (2015) “XVI. Yüzyıl Edirne'sinde Köle ve Cariyeler”, Asia Minor Studies, C: 3, S: 5, s. 147-170.

Zilfi, Madeline C. (2018) Osmanlı İmparatorluğu'nda Kölelik ve Kadınlar, İstanbul, Türkiye İş Bankası Kültür Yayınları. 